\title{
Understanding the Thermodynamics and Crystal Structure of Complex Fe Containing Intermetallic Phases Formed on Solidification of Aluminium Alloys
}

\author{
ALAN DINSDALE $\mathbb{1 0},{ }^{1,2}$ CHANGMING FANG $\odot{ }^{1},{ }^{1}$ ZHONGPING QUE,${ }^{1}$ \\ and ZHONGYUN FAN ${ }^{1}$ \\ 1.-BCAST, Brunel University London, Uxbridge UB8 3PH, UK. 2.—e-mail: alan.dinsdale@brunel.ac.uk \\ $\mathrm{Ab}$ initio density-functional theory calculations were carried out to investigate \\ the energetics and structure of key Fe-containing intermetallic phases that \\ precipitate from cast Al-Si alloys. These results were compared with published \\ experimental information and used to provide insight into developing im- \\ proved models to describe the thermodynamic properties of these phases.
}

\section{INTRODUCTION}

The control of harmful impurities such as Fe in cast $\mathrm{Al}-\mathrm{Si}$ alloys is becoming ever more important as the demand for the use of scrap materials increases. Traditionally manganese is added to prevent the formation of the harmful $\beta$-AlFeSi phase. Therefore, an understanding of phase equilibria in the $\mathrm{Al}-\mathrm{Fe}-$ $\mathrm{Mn}-\mathrm{Si}$ system, the solubilities of elements in various intermetallic phases and the temperatures at which they form are prerequisites for any successful control of the microstructure and the phases formed during solidification. The calculation of phase diagrams from critically assessed thermodynamic data provides an invaluable tool for providing such an understanding.

Critically assessed thermodynamic data are derived through careful analysis of all the experimental studies of thermodynamic properties and phase diagram information for a given system. Additionally, today such assessments should also consider the results of ab initio calculations, which may provide results with an accuracy equivalent to the best experimental work. Ab initio calculations may also be used to explore composition ranges of phases that are unstable and therefore inaccessible for study by experiment. In this way they can be used not just to provide key values for the critical assessment of data, but also assist in the selection of an appropriate thermodynamic model for a particular phase.

In this article, we considered in detail certain key phases of $\mathrm{Al}_{6} \mathrm{Mn}, \mathrm{Al}_{13} \mathrm{Fe}_{4}$ and $\alpha-\mathrm{Al}(\mathrm{Fe}, \mathrm{Mn}) \mathrm{Si}$, which may form during the solidification of commercial aluminium alloys. ${ }^{1-3}$ This included a thorough survey of published information on the thermodynamic properties, phase equilibria and crystal structures for these phases coupled to the calculation of the lattice parameters and enthalpies of formation using ab initio density-functional theory (DFT). These results allowed us to make key decisions related to the thermodynamic models used for these phases. An overview of the crystal structures of these phases is given in Table I.

\section{Thermodynamic Modelling and Structural Properties}

Despite its importance technologically, the phase diagram, thermodynamic properties and crystal structure of key intermetallic phases in the Al-FeMn-Si system are not completely understood. All of the published critical assessments of data for the system are largely based on the results of the COST507 European research programme. ${ }^{8-11}$ However, most of this work was carried out before reliable software and computer power made it possible to carry out detailed calculations on complex crystal structures in multicomponent systems using ab initio DFT.

Reliable thermodynamic modelling must be based on an understanding of the known crystal structure of a phase, e.g., the number of sublattices, the occupation of elements on the crystallographic sites and the energetics associated with vacancy formation. Some simplification is however sometimes necessary to minimise the number of parameters necessary to describe the thermodynamics of a 
Table I. Overview of the structural properties of the Al-rich Fe/Mn alloys

\begin{tabular}{|c|c|c|c|c|}
\hline Crystal & $\begin{array}{l}\text { Space group } \\
\text { (No.) }\end{array}$ & $\begin{array}{c}\text { Lattice param }_{(\AA)} \\
\end{array}$ & $\begin{array}{c}\text { Number of Wyckoff } \\
\text { sites }\end{array}$ & Remarks \\
\hline $\mathrm{Al}_{6} \mathrm{Mn}$ & $\begin{array}{c}\text { oC28 } \\
\text { orth. } \\
\text { Cmcm (63) }\end{array}$ & $\begin{array}{l}a=7.5518 \\
b=6.4978 \\
c=8.8703 \\
\quad(\text { Ref. } 4)\end{array}$ & $\begin{array}{l}\mathrm{Al}: 3 \\
\mathrm{Fe}: 1\end{array}$ & $\begin{array}{c}\text { Fixed stoichiometry in the Al-Mn } \\
\text { system but dissolves very large } \\
\text { amounts of Fe, which replaces Mn } \\
\text { in the crystal lattice }\end{array}$ \\
\hline $\mathrm{Al}_{13} \mathrm{Fe}_{4}$ & $\begin{array}{l}\text { Monoclinic } \\
\mathrm{mC} 102, \mathrm{C} 2 / \mathrm{m} \\
(12)\end{array}$ & $\begin{array}{c}a=15.492 \\
b=8.078 \\
c=12.471 \\
\beta=107.69^{\circ} \\
\quad(\text { Ref. } 5)\end{array}$ & $\begin{array}{l}\text { Al: } 15 \\
\text { Fe: } 7\end{array}$ & $\begin{array}{l}102 \text { atoms per unit cell. } \\
\text { Stable over a narrow range of } \\
\text { homogeneity in Al-Fe system but } \\
\text { dissolves substantial amounts of } \\
\text { Mn, which increases the range of } \\
\text { potential Al content }\end{array}$ \\
\hline $\begin{array}{l}\alpha-\mathrm{AlFeSi} \mathrm{Si} \\
\quad \mathrm{Al}_{19} \mathrm{Fe}_{4} \mathrm{MnSi}_{2}\end{array}$ & bcc $\operatorname{Im} 3$ (204) & $a=12.56$ (Ref. 6) & $\begin{array}{l}\text { Al: } 9 \\
\text { Fe: } 2\end{array}$ & $\begin{array}{l}138 \text { atoms per unit cell. } \\
\text { Stable over a wide range of } \\
\text { compositions with Fe and Mn } \\
\text { together occupying } 24 \text { sites and } \\
\text { Al and Si occupying } 114 \text { sites }\end{array}$ \\
\hline $\begin{array}{l}\alpha-\mathrm{AlMnSi} \\
\quad \mathrm{Al}_{9} \mathrm{Mn}_{2} \mathrm{Si}\end{array}$ & $P m-3$ (200) & $a=12.68($ Ref. 7$)$ & $\begin{array}{l}\text { Al: } 9 \\
\text { Fe: } 2\end{array}$ & $\begin{array}{l}138 \text { atoms per unit cell but seems } \\
\text { to have a primitive cubic structure }\end{array}$ \\
\hline
\end{tabular}

phase. Ab initio calculations now provide an invaluable tool by calculating the energetics of different crystallographic configurations to identify which features are key to guide such simplification. Furthermore, as many of the measurements of thermodynamic properties were carried out years ago, ab initio calculations provide the means to check the validity of such data. In this work such calculations have been employed to calculate the enthalpies of the formation, crystal structure and energetics associated with defect formation and the solution of additional elements onto the crystal lattice.

\section{Ab Initio Calculations}

For the calculations reported here, the plane wave method using VASP, Vienna Ab initio Simulation Package, was used. ${ }^{12,13}$ The spin-polarized generalized gradient approximation (SP-GGA-PBE) ${ }^{14}$ within the projector-augmented wave (PAW) method $^{15}$ was employed for the exchange and correlation energy terms because the spin-polarized generalized gradient approximation describes the $3 d$ transition metals such as Fe better than the (spin-polarized) local density approximation (LDA). ${ }^{16-19}$ The cut-off energy of the wave functions was set at $550 \mathrm{eV}$ and the cut-off energy of the augmentation functions was $700 \mathrm{eV}$ to describe the rather localized $\mathrm{Fe} 3 \mathrm{~d}$ orbitals. The electronic wave functions were sampled on dense $\mathrm{k}$ grids of the Brillouin zones of the unit cells. ${ }^{20}$ To obtain the ground state of the crystals, we performed calculations for different inputs. This avoided the possibility of our results falling into metastable solutions. ${ }^{16-18}$ Different k-meshes and cut-off energies were used for the waves and augmentation waves, respectively. Tests showed good convergence $(<1 \mathrm{meV} /$ atom $)$.

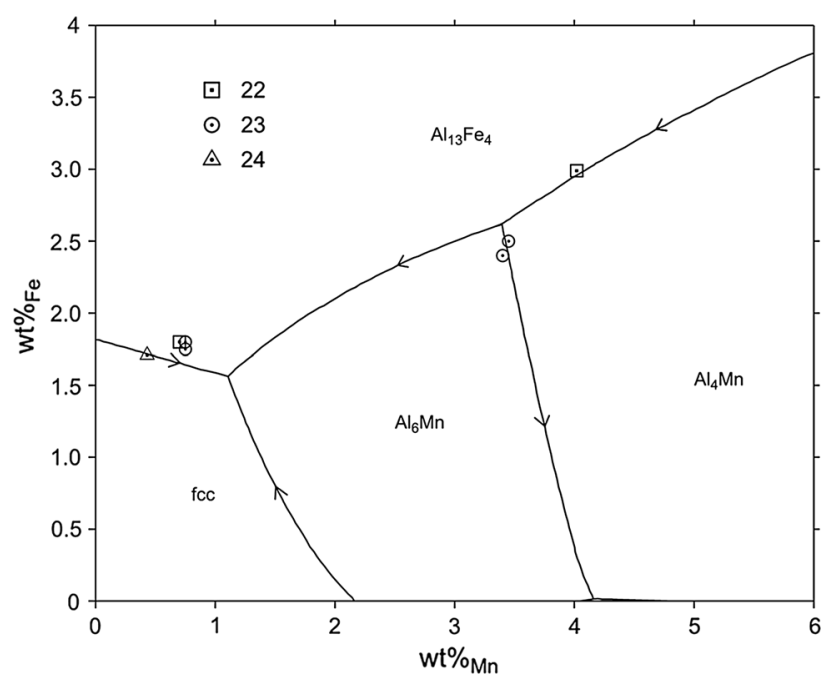

Fig. 1. Calculated liquidus project for the Al-rich corner of the Al-Fe$\mathrm{Mn}$ system from the assessed data of Lindahl and Selleby. ${ }^{21}$

\section{$\mathbf{A l}_{6} \mathbf{M n}$}

The most recent review as well as assessment of data for the Al-Fe-Mn system is from the work of Lin and Selleby. ${ }^{21}$ There are two invariant reactions in the Al-rich corner of the Al-Fe-Mn system, a eutectic reaction:

$$
\text { Liquid } \rightarrow \mathrm{Al}_{6} \mathrm{Mn}+\mathrm{Al}_{13} \mathrm{Fe}_{4}+\text { fcc }
$$

at $654^{\circ} \mathrm{C}$ and a probable ternary peritectic reaction at $730^{\circ} \mathrm{C}$ :

$$
\text { Liquid }+\mathrm{Al}_{13} \mathrm{Fe}_{4}+\mathrm{Al}_{4} \mathrm{Mn} \rightarrow \mathrm{Al}_{6} \mathrm{Mn}
$$

Figure 1 shows the calculated liquidus projection for the Al-rich corner of the system with key experimental values superimposed. The phase 
labelled "fcc" is the aluminium-based solid solution in which iron and manganese and, in the $\mathrm{Al}-\mathrm{Fe}-\mathrm{Mn}$ Si system, silicon dissolve in small amounts. $\mathrm{Al}_{13} \mathrm{Fe}_{4}$ is the most aluminium-rich intermetallic phase in the $\mathrm{Al}-\mathrm{Fe}$ system and often can precipitate from an aluminium-rich liquid containing relatively small amounts of iron. Other elements, particularly manganese, have appreciable solubility in this phase. $\mathrm{Al}_{6} \mathrm{Mn}$ is the most aluminium-rich intermetallic in the $\mathrm{Al}-\mathrm{Mn}$ system that is in equilibrium with the liquid phase. Of particular interest is the very high solubility of iron in this phase, which extends nearly all the way across the system to the Al-Fe system. The equivalent compound $\mathrm{Al}_{6} \mathrm{Fe}$ has been observed

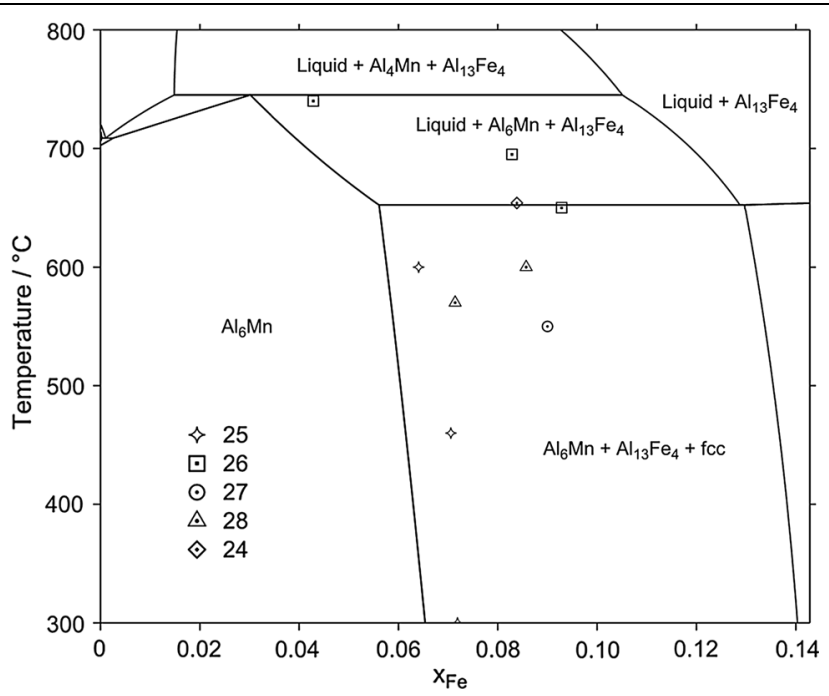

Fig. 2. Calculated isopleth between $\mathrm{Al}_{6} \mathrm{Mn}$ and $\mathrm{Al}_{6} \mathrm{Fe}$ using the data of Lindahl and Selleby. ${ }^{21}$ experimentally, but is considered to be metastable. $\mathrm{Al}_{6} \mathrm{Mn}$ has a bottom-centred orthorhombic (BCO) lattice with space group $\mathrm{Cmcm}$ (No. 63). There are three crystallographically different species of $\mathrm{Al}$ with 28 atoms per unit cell.

Figure 2 shows a calculated isopleth in the Al-Fe$\mathrm{Mn}$ system from $\mathrm{Al}_{6} \mathrm{Mn}$ to the composition of $\mathrm{Al}_{6} \mathrm{Fe}$. It shows the appreciable solubility of $\mathrm{Fe}$ in the phase. Experimental phase equilibrium data are superimposed.

$\mathrm{Ab}$ initio DFT calculations have been carried out to explore the crystal structure of the $\mathrm{Al}_{6} \mathrm{Mn}$ in detail to identify which crystallographic site iron atoms are likely to replace aluminium and to consider the possibility of solution of silicon in the phase. Figure 3a shows that the substitution of Mn by $\mathrm{Fe}$ is predicted to be accompanied by a heat release of $2.8 \mathrm{~kJ} \mathrm{~mol}^{-1}$ per formula unit for substitution of half of the Mn by Fe. Figure 3b shows the excellent agreement between the calculated lattice parameters and the experimental values. ${ }^{29}$ The potential for $\mathrm{Si}$ substituting for $\mathrm{Al}$ in the $\mathrm{Al}_{6} \mathrm{Mn}$ lattice was also explored and shows that this is accompanied by a large enthalpy increase, i.e., substitution is not favoured.

\section{$\mathrm{Al}_{13} \mathrm{Fe}_{4}$}

Figures 1 and 2 show that $\mathrm{Al}_{6} \mathrm{Mn}$ is in equilibrium with $\mathrm{Al}_{13} \mathrm{Fe}_{4}$ in the $\mathrm{Al}-\mathrm{Fe}-\mathrm{Mn}$ system. Just as $\mathrm{Fe}$ substitutes for $\mathrm{Mn}$ in the $\mathrm{Al}_{6} \mathrm{Mn}$ phase, the $\mathrm{Al}_{13} \mathrm{Fe}_{4}$ phase is capable of dissolving substantial amounts of $\mathrm{Mn}$. However, in the binary $\mathrm{Al}-\mathrm{Fe}$ system the $\mathrm{Al}_{13} \mathrm{Fe}_{4}$ phase exists only over a relatively narrow range of homogeneity (maximum 4 at.\%) that, according to recent experimental work, ${ }^{30}$ becomes smaller as the temperature is reduced.

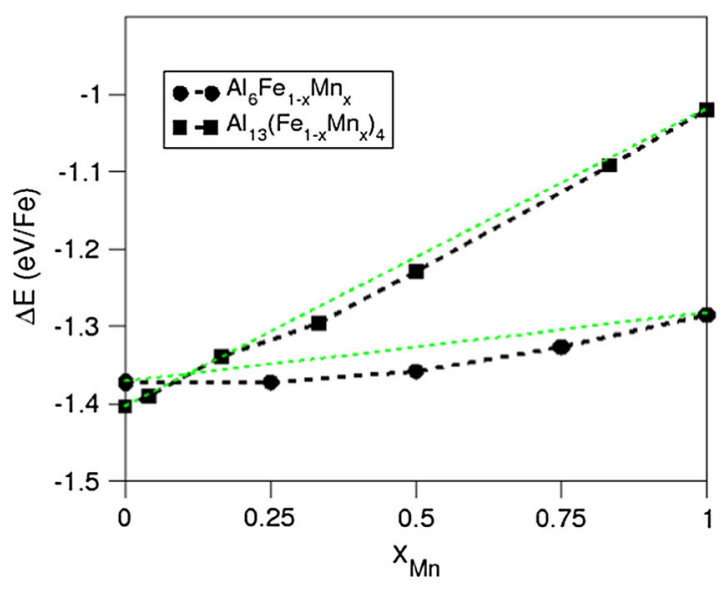

(a)

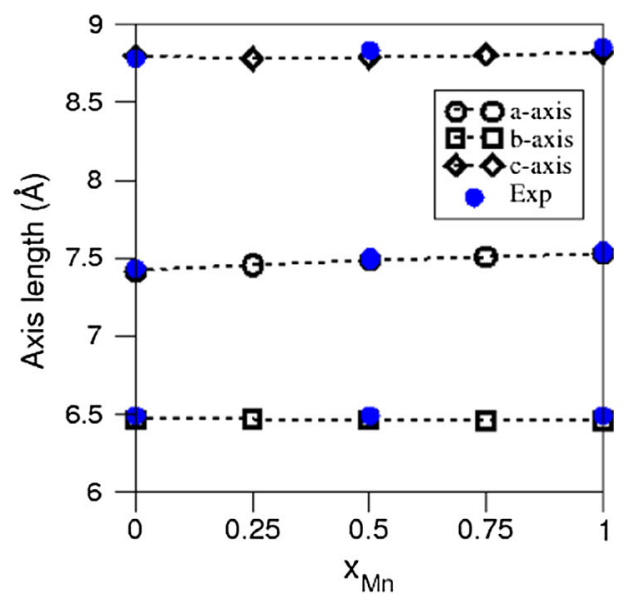

(b)

Fig. 3. (a) Calculated formation energy ( $\Delta \mathrm{E}$, meV/atom) associated with the solution of $\mathrm{Fe}$ in $\mathrm{Al}_{6} \mathrm{Mn}$ and $\mathrm{Mn}$ in $\mathrm{Al}_{13} \mathrm{Fe}_{4}$ and (b) the calculated lattice parameters for the solution of $\mathrm{Fe}$ in $\mathrm{Al}_{6} \mathrm{Mn}$. The dashed green lines in a indicate the averaged formation energy between the intermetallic compounds on the Al-Fe and Al-Mn systems. The filled spheres in (b) represent the experimental data. ${ }^{29}$ 
The crystal structure of stoichiometric $\mathrm{Al}_{13} \mathrm{Fe}_{4}$ is now well defined. ${ }^{5,31-35}$ It has a total of 102 atomic sites per unit cell, 78 occupied by $\mathrm{Al}$ and 24 by Fe. If all lattice sites are occupied, this gives the composition $\mathrm{Al}_{78} \mathrm{Fe}_{24}$, i.e., $\mathrm{Al}_{13} \mathrm{Fe}_{4}$, and this represents the most Al-rich composition of the phase according to the phase diagram. There appear to have been no detailed crystal structure determinations on compositions away from stoichiometry to indicate where defects arise (from either vacancy formation or substitution). So far, the thermodynamic models for the phase have all been based on the assumption of vacancy formation on some of the aluminium sites. This has been successful in modelling the thermodynamic properties to calculate the phase diagram for the Al-Fe system, but, because it is not based on any firm foundation, is not able to provide a good basis for representing data for ternary systems such as the Al-Fe-Mn system where substitution of $\mathrm{Mn}$ is complex.

The enthalpy of formation of $\mathrm{Al}_{13} \mathrm{Fe}_{4}$ has been measured calorimetrically ${ }^{36-38}$ and calculated using ab initio DTF at $0 \mathrm{~K}^{39,40}$ The calculated values are very close but significantly more negative than the calorimetric data.

We also studied the energetics (Fig. 4) associated with defect formation on the various sites of the $\mathrm{Al}_{13} \mathrm{Fe}_{4}$ lattice. ${ }^{40}$ The formation of vacancies was shown to be energetically highly unfavourable, which is in contrast to the commonly used thermodynamic model for the phase, which draws on the experimental work of Grin et al. ${ }^{5}$ for the stoichiometric composition. Further calculations showed that substitution of $\mathrm{Fe}$ in three aluminium sites is much more favourable energetically and led to the development of a new thermodynamic model for the phase:

$$
(\mathrm{Al})_{68}(\mathrm{Fe})_{24}(\mathrm{Al}, \mathrm{Fe})_{4}^{\mathrm{IX}}(\mathrm{Al}, \mathrm{Fe})_{2}^{\mathrm{VII}}(\mathrm{Al}, \mathrm{Fe})_{4}^{\mathrm{V}}
$$

where the Roman numerals IX, VII and V indicate the appropriate crystallographic site. This allows for a wider range of homogeneity than is necessary for the Al-Fe system itself but would be necessary to model the extent of the homogeneity range of the phase in the Al-Fe-Mn system. ${ }^{26,27}$ The calculations also show that the substitution of $\mathrm{Fe}$ onto $\mathrm{Al}$ sites induces magnetism. The nature of this magnetic ordering is quite complicated depending on the nature of the site or sites in which the Fe atoms substitute. On the whole, the ordering is predicted to be ferromagnetic but certain arrangements of atoms are predicted to give rise to antiferromagnetic or ferrimagnetic ordering. Further calculations were also carried out to investigate the effect of substituting Fe by Mn (Fig. 3a).

\section{$\alpha-\mathbf{A l}(\mathbf{F e}, \mathbf{M n}) \mathrm{Si}$}

The cubic $\alpha-\mathrm{Al}(\mathrm{Fe}, \mathrm{Mn}) \mathrm{Si}$ phase (also known as $\left.\mathrm{Al}_{15}(\mathrm{Fe}, \mathrm{Mn})_{3} \mathrm{Si}_{2}\right)$ forms as a large crystal of the primary intermetallic phase on solidification of

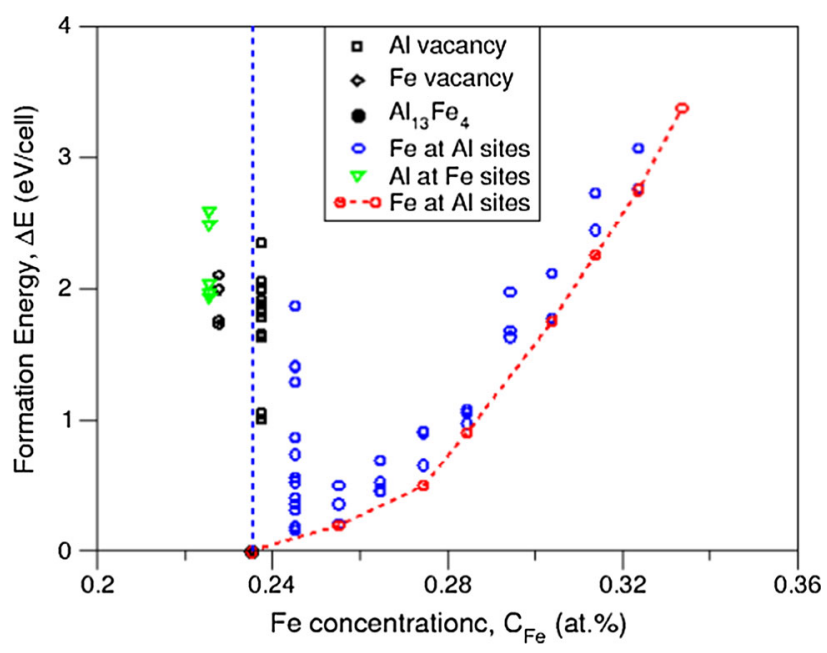

Fig. 4. Calculated formation energies (eV/cell) at $0 \mathrm{~K}$ associated with the introduction of intrinsic defects into the unit cell of $\mathrm{Al}_{13} \mathrm{Fe}_{4}$. The vertical dotted blue line represents the stoichiometric composition. The dotted red curve connects the most stable configurations.

many commercial $\mathrm{Al}$ alloys. It also forms with a "Chinese script" morphology during a subsequent eutectic reaction. The exact nature of this phase has been the subject of much uncertainty over the years and this has not been helped by the confusing and inconsistent terminology adopted for the various intermetallic phases in the quaternary system. To this end, in this article we will refer to $\mathrm{Al}_{7.4} \mathrm{Fe}_{2} \mathrm{Si}$ (sometimes referred to as the $\alpha-\tau_{5}$ phase and $\alpha$ $\mathrm{AlFeSi}$ ) and $\mathrm{Al}_{9} \mathrm{Mn}_{2} \mathrm{Si}$ (sometimes referred to as $\alpha$ AlMnSi). In their pioneering work, Phillips and Varley ${ }^{41}$ did not distinguish between $\mathrm{Al}_{9} \mathrm{Mn}_{2} \mathrm{Si}$ and the $\mathrm{Al}_{7.4} \mathrm{Fe}_{2} \mathrm{Si}$ and assumed that they formed a cubic solid solution phase across the system. Munson ${ }^{42}$ showed that while $\mathrm{Al}_{9} \mathrm{Mn}_{2} \mathrm{Si}$ is cubic, $\mathrm{Al}_{7.4} \mathrm{Fe}_{2} \mathrm{Si}$ is hexagonal and therefore the two phases could not form a continuous solid solution. Other work ${ }^{29,43-45}$ showed that the cubic $\alpha-\mathrm{Al}(\mathrm{Fe}, \mathrm{Mn}) \mathrm{Si}$ emanates from $\mathrm{Al}_{9} \mathrm{Mn}_{2} \mathrm{Si}$ by substantial substitution of $\mathrm{Mn}$ by $\mathrm{Fe}$ but that it did not extend to the Al-Fe-Si system. They also showed that the phase had a broad range of homogeneity with respect to the Si content. On the other hand, others have identified quaternary phases. ${ }^{46-49}$

The confusion has been partially resolved by Krendelsberger. ${ }^{50-52}$ As part of a comprehensive study of the Al-Fe-Si, Al-Mn-Si and Al-Fe-Mn-Si systems, she studied the section between $\mathrm{Al}_{9} \mathrm{Mn}_{2} \mathrm{Si}$ and $\mathrm{Al}_{7.4} \mathrm{Fe}_{2} \mathrm{Si}$ at $700^{\circ} \mathrm{C}$. She carried out a full structure analysis of single-phase samples corresponding to $\mathrm{Al}_{9} \mathrm{Mn}_{2} \mathrm{Si}$ and an $\alpha-\mathrm{Al}(\mathrm{Fe}, \mathrm{Mn}) \mathrm{Si}$ containing approximately equal amounts of $\mathrm{Fe}$ and $\mathrm{Mn}$. She was able to confirm that both samples had close to an identical cubic crystal structure with 138 atoms per unit cell. However, the $\mathrm{Al}_{9} \mathrm{Mn}_{2} \mathrm{Si}$ sample showed a simple primitive cubic lattice while the $\alpha$ $\mathrm{Al}(\mathrm{Fe}, \mathrm{Mn}) \mathrm{Si}$ sample had a bcc structure in which some of the peaks had disappeared. It is still unclear 
whether this indicates that a first- or second-order phase transformation takes place on the addition of Fe to $\mathrm{Al}_{9} \mathrm{Mn}_{2} \mathrm{Si}$.

$\mathrm{Ab}$ initio calculations have been carried out to help understand this issue. Based on our experience with the calculations on the $\mathrm{Al}_{13} \mathrm{Fe}_{4}$ phase and the experimental crystal structure model for $\alpha$ $\mathrm{Al}(\mathrm{Fe}, \mathrm{Mn}) \mathrm{Si}$, we built a framework for DFT calculations with $24 \mathrm{Fe}$ atoms occupying the two 12j sites and the remaining nine Wyckoff sites occupied by $\mathrm{Al}$. This unit cell contains $24 \mathrm{Fe}$ and $114 \mathrm{Al}$ atoms. As expected, the calculated formation energy is noticeably higher than that of $\mathrm{Al}_{13} \mathrm{Fe}_{4}$. Then, in subsequent calculations, we replaced Fe by $\mathrm{Mn}$ and $\mathrm{Al}$ by $\mathrm{Si}$ in a systematic way. Further calculations were carried out to examine the effect of substitution of $\mathrm{Al}$ by $\mathrm{Fe}$ or $\mathrm{Mn}$.

The results clearly show that mixing of $\mathrm{Fe}$ and $\mathrm{Mn}$ on the two $12 \mathrm{j}$ sites is favoured although one set of sites seemed more favourable for substitution than the other. More calculations are currently underway and it is hoped, that they will shed more light on the chemical compositions and related symmetry, crystal structure, energetics and electronic properties of the $\alpha-\mathrm{Al}(\mathrm{Fe}, \mathrm{Mn}) \mathrm{Si}$ compound.

\section{CONCLUSION}

Experimental phase diagram, thermodynamic and crystal structure data for three key Fe-based intermetallic phases that precipitate from cast $\mathrm{Al}-\mathrm{Si}$ alloys were reviewed. Ab initio DFT calculations were employed to better understand the non-stoichiometry in these phases in terms of the defects. In all of the phases studied there was a marked tendency for $\mathrm{Fe}$ and $\mathrm{Mn}$ to mix on the same crystallographic sites with a negative enthalpy of mixing relative to the pure constituent compounds (Fig. 3a). For the $\mathrm{Al}_{13} \mathrm{Fe}_{4}$ phase it was shown that the relatively narrow range of homogeneity in the $\mathrm{Al}-\mathrm{Fe}$ system is due to the substitution of Fe atoms on three specific $\mathrm{Al}$ sites. This is in contrast to the accepted thermodynamic description, which introduced vacancies. Our calculations show that this is highly unfavourable energetically.

\section{ACKNOWLEDGEMENTS}

The study was funded by Engineering and Physical Sciences Research Council (Grant No. EP/ N007638/1).

\section{OPEN ACCESS}

This article is distributed under the terms of the Creative Commons Attribution 4.0 International License (http://creativecommons.org/licenses/by/4.0/ ), which permits unrestricted use, distribution, and reproduction in any medium, provided you give appropriate credit to the original author(s) and the source, provide a link to the Creative Commons license, and indicate if changes were made.

\section{REFERENCES}

1. Z.P. Que, Y.P. Zhou, Y. Wang, and Z. Fan, Trans. Indian Inst. Met. 68, 1167 (2015).

2. Z.P. Que, Y. Wang, Y.P. Zhou, and Z. Fan, Mater. Sci. Forum 828-829, 53 (2015).

3. Z.P. Que, Y. Wang, and Z. Fan, Metall. Mater. Trans. A 49A, 2173 (2018).

4. W.B. Pearson, A handbook of lattice spacings and structures of metals and alloys, Vol. 2 (Oxford: Pergamon Press, 1967).

5. J. Grin, U. Burkhardt, M. Ellner, and K. Peters, Z. Kistallogr. 209, 479 (1994).

6. M. Cooper, Acta Cryst. 23, 1106 (1967).

7. M. Cooper and K. Robinson, Acta Cryst. 20, 614 (1966).

8. I. Ansara, A.T. Dinsdale, and M.H. Rand, eds., COST507, Thermochemical database for light metal alloys, Vol. 1 (Luxembourg: Office for official publications of the European Communities, 1998).

9. Y. Du, Y.A. Chang, S. Liu, B. Huang, F.-Y. Xie, Y. Yang, and S.-L. Chen, Z. Metallkde. 96, 1351 (2005).

10. J. Lacaze, L. Eleno, and B. Sundman, Metall. Mater. Trans. A 41, 2208 (2010).

11. E. Balitchev, T. Jantzen, I. Hurtado, and D. Neuschutz, CALPHAD 27, 275 (2003).

12. G. Kresse and J. Hafner, Phys. Rev. B 49, 14251 (1994).

13. G. Kresse and J. Furthmüller, Comput. Mater. Sci. 6, 15 (1996).

14. J.P. Perdew, K. Burke, and M. Ernzerhof, Phys. Rev. Lett. 77, 3865 (1996).

15. P.E. Blöchl, Phys. Rev. B 50, 17953 (1994).

16. C.M. Fang, M.H.F. Sluiter, M.A. van Huis, and H.W. Zandbergen, Phys. Rev. Lett. 105, 055503 (2010).

17. C.M. Fang and M.A. van Huis, Heliyon 3, e00408 (2017).

18. C.M. Fang, M.A. van Huis, and M.H.F. Sluiter, Acta Mater. 103, 273 (2016).

19. C. Amador, W.R.L. Lambrecht, and B. Segall, Phys. Rev. B 46, 1870(R) (1992).

20. H.J. Monkhorst and J.D. Pack, Phys. Rev. B 13, 5188 (1976).

21. B.B. Lindahl and M. Selleby, CALPHAD 43, 86 (2013).

22. E. Degischer, Alum Arch. 18, 5 (1939).

23. H.W.L. Phillips, J. Inst. Metals 69, 275 (1943).

24. W.T. Denholm, J.D. Esdaile, N.G. Siviour, and B.W. Wilson, Metall. Trans. A 15, 1311 (1984).

25. G.V. Raynor, J. Inst. Metal. 70, 531 (1944).

26. S. Balanetskyy, D. Pavlyuchkov, and T. Velikanova, B. Grushko. J. Alloys Compounds 619, 211 (2015).

27. F. Weitzer, P. Rogl, and M. Bohn, COST507, Thermochemical Database For Light Metal Alloys, Vol. 1 (Luxembourg: Office for Official Publications of the European Communities, 1998), p. 53.

28. M.C. Thornton and P.V. Evans, Alcan International. Unpublished research referred to by A. Jansson, T.G. Chart, COST507, Thermochemical Database For Light Metal Alloys, vol 1, (Office for Official Publications of the European Communities, Luxembourg 1998), p. 257.

29. J.G. Barlock and L.F. Mondolfo, Z. Metallkde. 66, 605 (1975).

30. K. Han, I. Ohnuma, and R. Kainuma, J. Alloys Compounds 668, 97 (2016).

31. P.J. Black, Acta Crystallogr. 8, 43 (1955).

32. P.J. Black, Acta Crystallogr. 8, 175 (1955).

33. R.C. Hudd and W.H. Taylor, Acta Cryst. 15, 441 (1962).

34. A. Griger, V. Sterfaniay, and T. Turmezy, Z. Metallkde. 77, 30 (1986)

35. T.I. Yanson, N.B. Manyako, O.I. Bodak, R. Cêrny, R.E. Gladyshevskii, and K. Yvon, J. Alloys Compounds 219, 135 (1995).

36. W. Biltz, Z. Metallkde. 29, 73 (1937).

37. O. Kubaschewski and W.A. Dench, Acta Metall. 3, 339 (1955).

38. W. Oelsen and W. Middel, Mitt. KW Inst. Eisenforschung 19 , 1 (1937).

39. M. Mihalkovič and M. Widom, Phys. Rev. B 85, 014113 (2012). 
40. C.M. Fang, A.T. Dinsdale, Z.P. Que, and Z. Fan, J. Phys. Mater. 2, 15004 (2019).

41. H.W.L. Phillips and P.C. Varley, J. Inst. Met. 69, 317 (1943).

42. D. Munson, J. Inst. Met. 95, 217 (1967).

43. C.Y. Sun and L.F. Mondolfo, J. Inst. Met. 95, 384 (1967).

44. G. Davignon, A. Serneels, B. Verlinden, and L. Delaey, Metall. Mater. Trans. A 27A, 3357 (1996).

45. J.E. Tibbals, J.A. Horst, and C.J. Simensen, J. Mater. Sci. 36, 937 (2001).

46. A.M. Zakharov, I.T. Gul'din, A.A. Arnol'd, and Y.A. Matsenko, Izvest. Akad. Nauk SSSR, Metally 4, 214 (1989); Russ. Metall. 4, 209 (1989).

47. A. Flores-Valdes, M.I. Pech-Canul, M. Mendez-Nonell, and M. Sukiennik, Scr. Metall. Mater. 30, 435 (1994).

48. A. Flores-Valdes, M. Sukiennik, A.H. Castillejos-Escobar, F.A. Acosta-Gonzalez, and M. Mendez-Nonell, Arch. Metall. 41, 294 (1996).
49. M. Sukiennik, A. Flores-Valdes, A.H. Castillejos-Escobar, F.A. Acosta-Gonzalez, and M.I. Pech-Canul, Arch. Metall. 42,25 (1997).

50. N. Krendelsberger, in Ph.D.Thesis (Innovative Materials Group, Universitat Wien, Vienna, 2001).

51. N. Krendelsberger, F. Weitzer, and J.C. Schuster, Metall. Mater. Trans. A 33A, 3311 (2002).

52. N. Krendelsberger, F. Weitzer, and J.C. Schuster, Metall. Mater. Trans. A 38A, 1681 (2007).

Publisher's Note Springer Nature remains neutral with regard to jurisdictional claims in published maps and institutional affiliations. 